\title{
DO RIVERS UPSTREAM WEIRS HAVE LOTICS OR LENTICS CHARACTERISTICS?
}

\author{
Francesco DONATI ${ }^{1}$, Laurent TOUCHART ${ }^{2}$, Pascal BARTOUT ${ }^{3}$
}

DOI: 10.21163/GT_2019.142.01

\begin{abstract}
:
In France the multitude of weirs that exist in rivers could affect the quality of aquatic ecosystems. The current context of recovery of the good state of watercourses, dictated by the European Water Framework Directive, requires understanding of their impact, in order to address operations of river restoration. One of the risks connected to this kind of structure is the loss of lotics characteristics of streams, in favour of lentics characteristics. In fact, they cause a reduction in speed flow, favouring the formation of zones with lentic flow. Through the study of thermal stratification, the major discriminant between running and stagnant waters, the aim of this study is to understand the nature of rivers situated upstream weirs, using four study sites. Results show that the presence of a weir is not synonymous of substitution of the lotic characteristics of a watercourse. Lentic behavior of waters has only been observed when certain environmental and hydrological conditions have been met in the reach.
\end{abstract}

Key-words: Weirs, Thermal stratification, River ecosystem, Water Framework Directive.

\section{INTRODUCTION}

In Europe, the context of improvement and preservation of water quality dictated by the Water Framework Directive requires the identification of the causes of alteration of aquatic environment, to guide renaturation efforts (Roche, et al., 2005). The profuse of hydraulic structures that characterize fluvial landscapes of Europe are one of the possible causes of the degradation of river quality (e.g. Tricart et al., 1991). Therefore, it is crucial for water resources administrators to determine the impact of this type of infrastructures.

The rivers of metropolitan France are potentially exposed to degradation caused by hydraulic structures, because of their diffusion on the country's rivers. Among these structures there are weirs, omnipresent within the French hydrographic network. In a watercourse, the presence of a weir causes a modification of its hydraulic conditions, whose most remarkable effect is the formation of a zone of slow flow velocity upstream (Csiki \& Rhoads, 2010). This speed reduction could be such as to provoke a sort of dam effect, favouring the formation of zones of lentic flow (Malavoi \& Salgues, 2011) and the substitution of lotic features of the watercourse by lentic characteristics (Souchon \& Nicolas, 2011), but studies to confirm or invalidate it are missing for French contexts.

Are watercourses upstream weirs converted into stagnant water bodies or do they retain their current water characteristics? Through French case studies, using the water temperature parameter, which is the main cause of water density stratification, the objective of this study is to try and answer to this question to give a better understanding of the effects of weirs on aquatic environments.

\footnotetext{
1,2,3 Université d'Orléans, Département de Géographie, 45065 Orléans, France, francesco.donati@univ-orleans.fr, laurent.touchart@univ-orleans.fr,pascal.bartout@univorleans.fr.
} 


\section{STUDY AREA}

To provide an answer to the issue, two study areas were equipped, chosen in climatic contexts typical of metropolitan France, to consider two types of hydro-climatic situations. The first site is in the Mauves river, a tributary of the Loire river that flows for $45 \mathrm{~km}$ in the department of Loiret, in the west of the Orleans agglomeration. The geology of its watershed is mainly characterised by Beauce limestone and sediments of different types from the Cenozoic period (Ausilio, 1984). Overall, the forest cover of this territory is weak, but throughout the banks of the Mauves grows a dense riparian forest, which in some places assumes the features of a veritable alluvial forest, as in correspondence of the Departmental Natural Park of "Courtils des Mauves», located in the village of Meung sur Loire. A degraded oceanic climate characterises this area (Escourrou, 1982): the nearest weather station (that one of Bricy), over the period 1981-2010, measured an average temperature of $11.2^{\circ} \mathrm{C}$ and average rainfall of $642 \mathrm{~mm}$ (infoclimat.fr data). The average flow of the Mauves is $1.075 \mathrm{~m} 3 / \mathrm{s}$ (BanqueHydro data). This study area consists of three distinct water mill reaches: the most upstream is the Nivelle mill one, the central is the Marais mill one and the further downstream is the St. Hilaire mill one. Respectively, they measure about 900, 400 and 500 meters. The first and second reaches are consecutive to each other, the last is separated from the others by the short reach of another mill. The three mills are equipped with a weir, whose height is between 0.5 and 1 meter (ROE data), with valve.

The second site is in the North Zinsel river, a tributary of the Moder river which flows for $43 \mathrm{~km}$ between the departments of Moselle (57) and Bas-Rhin (67), in the North-East of France. From a geological point of view, it is in the Vosges du Nord massif and the watershed, whose outlet is the study area, is entirely characterized by Vosgian sandstone of lower Trias and Buntsandstein. 94\% of the land cover of this territory is characterized by forest. The oceanic climate influence is even more degraded, and it is exacerbated by altitude (Escourrou, 1982, op.cit): the closest weather station (that of Mouterhouse), over the period 1981-2010, measured a temperature average of $9.5^{\circ} \mathrm{C}$ and an average rainfall of $989.8 \mathrm{~mm}$ (infoclimat.fr data). In correspondence of the study area, the average flow of the Zinsel du Nord is $0.596 \mathrm{~m}^{3} / \mathrm{s}$ (Parc Naturel Régional des Vosges du Nord data). This study area consists of a reach of about 200 meters, circumstantiated downstream by a weir 1.50 meters high, located in the downtown of the village of Baerenthal. In the upstream part of the reach the stream hasn't got any riparian vegetation, unlike the central and final parts, where several trees shade the stream.

\section{METHODOLOGY}

\subsection{The techniques and instruments used to differentiate the lotic and lentic operation of rivers upstream weirs}

To understand if rivers upstream weirs retain their lotic features or they have lentic characteristics, the methodology deployed is based on the study of the thermal properties of the water. Indeed, the major discriminant between running and stagnant waters is the thermal stratification of the water column (Wilhem, 1960; Touchart, 2002). Although it has moments of uniformity, the normality of a stagnant water is its stratification according to a vertical temperature-density gradient, whereas the normality of a running water is the physicochemical homogeneity of the water column, because turbulence prevents the distinction of water layers and their superposition (Touchart, 2007, a). Therefore, the 
portions of watercourses upstream weir were studied as if they were lentic ecosystems, with techniques that are commonly used in limnology.

The temperature of the water column was measured using chains of thermometers. This device is widely used for the thermal study of lakes or ponds and it allows to measure the temperature of the water at different depths and see if there are thermal gradients between the surface and the bottom (Touchart, 2001; Touchart 2002, op cit; Choffel et al., 2017). Although it is a typical instrument for limnological works, this tool has already been used in fluvial areas and upstream of weirs (eg Bormans et al., 1997; Webster et al., 1997). The chains used for this research consist of an 8mm-diameter mesh, one end of which was attached to a buoy with a circumference of $25 \mathrm{~cm}$. Although the chain was already considerably heavy, the other end was attached to a large concrete block, in order to anchor the device securely to the stream bed. Two recording thermometers (HOBO Water

Temperature Pro v2 Data Logger - U22-001, with an accuracy of $\pm 0.21^{\circ} \mathrm{C}$ and a resolution of $0.02^{\circ} \mathrm{C}$ at $25^{\circ} \mathrm{C}$ ) were attached to the chain and programmed to measure the temperature of the water with a time step of 60 minutes.

In the Mauves a thermometer was attached $10 \mathrm{~cm}$ below the surface of the water, and the second at a depth of $50 \mathrm{~cm}$; in the North Zinsel, too, a thermometer was attached $10 \mathrm{~cm}$ below the water surface, but the second was placed at a $70 \mathrm{~cm}$ depth. In both cases a piece of chain was left between the deepest thermometer and the stream bed, so that the device followed the fluctuations of the water level and the probe never touched the bottom. The thermometers were set up on 02/02/2018 in the Zinsel of the North and on 24/02/2018 in the Mauves and they worked until 31/12/2018, collecting a total of 35,529 water temperature data. At the Nivelle water mill, the data relating to the period from the end of September to the beginning of December were lost.

\subsection{Choice of instruments location}

In the four study areas, the chains of thermometers were positioned where the flow was slowest to collect the data where the conditions were as lentic as possible. To determine the location of the instruments a preliminary study of the velocities in the reaches was carried out. Four equally spaced transects were established and on these the flow velocity was measured using a current meter (Flowtracker 2 with an accuracy of $\pm 1 \%$ for a measured speed of $+0.0025 \mathrm{~m} / \mathrm{s}$ and a resolution of $0.0001 \mathrm{~m} / \mathrm{s}$ ).

The methodology used is the same for the measurement of discharge through the exploration of velocity field described in Le Coz, et al. (2011): each transect was divided into a $n$ number of verticals, on which velocities were sampled in several points. The number and the depth of each point were established following the indications of the current meter. Then the average speed was calculated for each transect and the thermometers were installed in the area where the velocity values were the lowest.

\subsection{Data analysis}

In order to understand if the water column has thermal stratifications and determine their intensity, the hourly delta $\Delta$ between surface temperature and depth was calculated. The temporality of thermal stratifications was studied through the daily $\Delta_{\min }$, the minimum thermal difference between the surface and the bottom of the water column during a day: when $\Delta_{\min }$ is equal to 0 the thermal stratification lasts less than 24 hours. Any value within the error range of thermometers has been recorded as $\Delta=0$. 

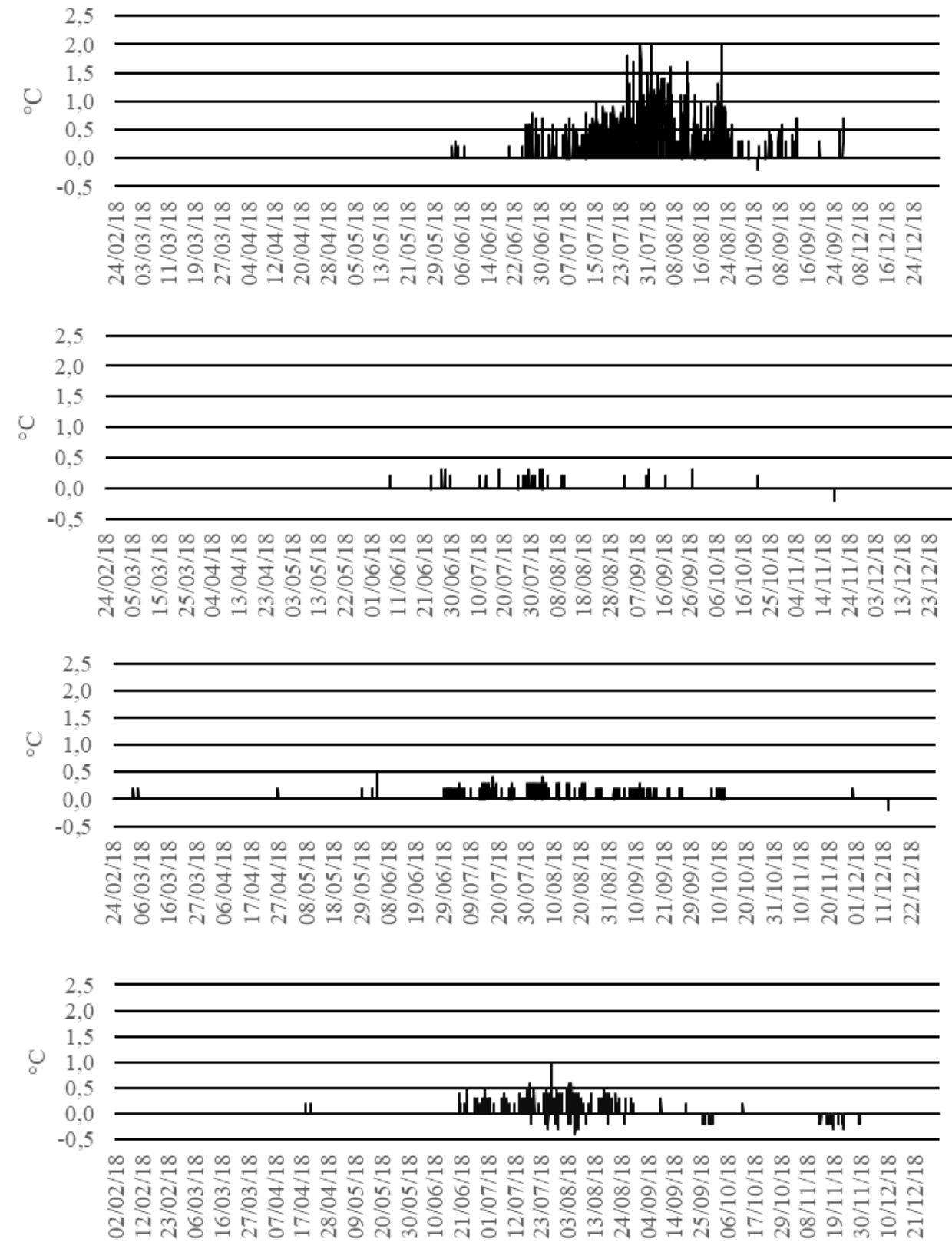

Fig. 1. The evolution of delta in the water column of study areas. From the top to the bottom: Nivelle Water mill, Marais water mill, St. Hilaire water mill, Baerenthal reach. 

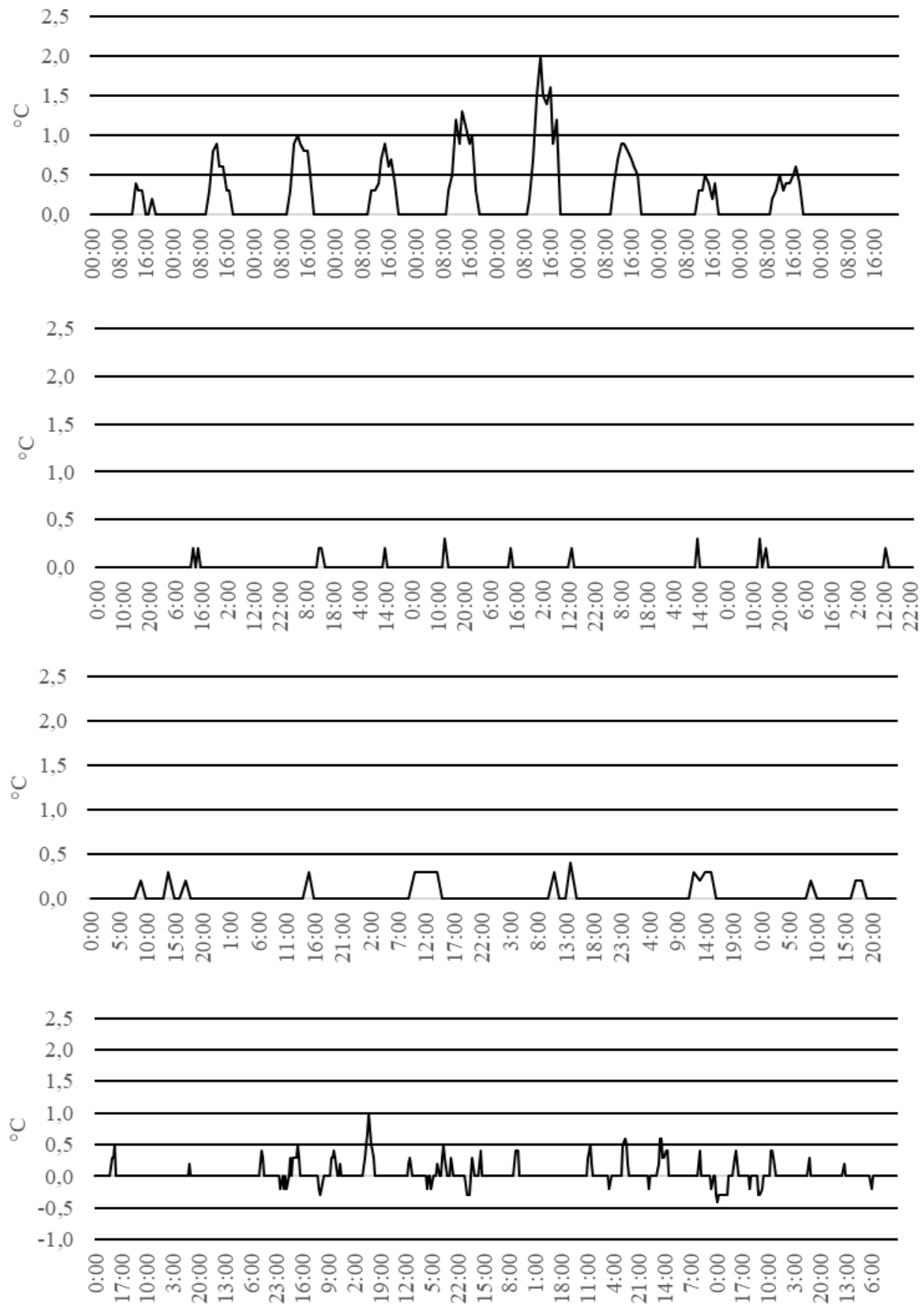

Fig. 2. The evolution of delta in the water column of study areas, during the longer periods of thermal stratification. From the top to the bottom: Nivelle Water mill (17/08-26-08), Marais water mill (25/07-05/08), St. Hilaire water mill (03/08-09/08), Baerenthal's reach (20/07-10/08). 


\section{RESULTS AND DISCUSSIONS}

Graphs in Fig. 1 show the evolution of the thermal delta between the two extremes of the water column of the four reaches under study. Overall, it is possible to single out two moments: one during which the values of $\Delta$ fall within the margin of error of thermometers, during Winter, Spring and Autumn, and another during which $\Delta$ is greater than this interval, during the Summer. From 21/06 to 23/09, the Nivelle water mill reach is the one with the most marked thermal heterogeneity of the water column: on average, $\Delta$ was $0.6^{\circ} \mathrm{C}$, with peaks of $2^{\circ} \mathrm{C}$. In the other reaches on the Mauves $\Delta$ values are less important, averaging $0.2^{\circ} \mathrm{C}$ in the two study areas, with peaks of $0.3^{\circ} \mathrm{C}$ at the Marais water mill and $0.4^{\circ} \mathrm{C}$ that of St. Hilaire. Baerenthal $\Delta$ has mean values of $0.3^{\circ} \mathrm{C}$ and peaks of $1^{\circ} \mathrm{C}$; here $\Delta$ also reached negative values, when the water at surface was colder than water at depth, whose maximum value was $-0.4{ }^{\circ} \mathrm{C}$. We suppose that these moments of negative delta, which occurred almost always during the night, are due to the convective cooling of the water which determines a heat loss of the layers close to the surface (Lemmin, 1995).

From a temporal point of view, also the Nivelle water mill is the one which presents the more important values, with a total of 545 hours of heterothermia (supposing that during the period during which the data were lost $\Delta=0$, this number corresponds to $7 \%$ of the study period and $19 \%$ of the summer period). At the Marais and St. Hilaire water mills, this value is respectively 32 and 143 hours (the, $0.4 \%$ and $1.9 \%$ of the study period and $1 \%$ and $4 \%$ of the summer period) and in Baerenthal 204 hours (the 2\% of the study period and $5 \%$ of the summer period). The moments of $\Delta \neq 0$ never last for long periods, but they are rather episodic, lasting only some hours within a day. Averaging, at the Nivelle water mill the moment of heterothermia lasted 6 hours (maximum duration 15 hours on 12/08), in the water mills of Marais and St. Hilaire 1 hour (maximum duration respectively of 3 hours on 27/09 and 5 hours the 05/08) and in Baerenthal 2 hours (maximum duration 12 hours on 06/08). In each field of study, the daily $\Delta_{\min }$ was always 0 , which means that at least one moment of the day the water column was homothermal. If we deepen the temporality of the episodes of $\Delta \neq 0$ we realize that most take place between the end of the morning and the first hours of the afternoon, between 12:00pm and 3:00pm, as we can see from the graph in Fig. 3.

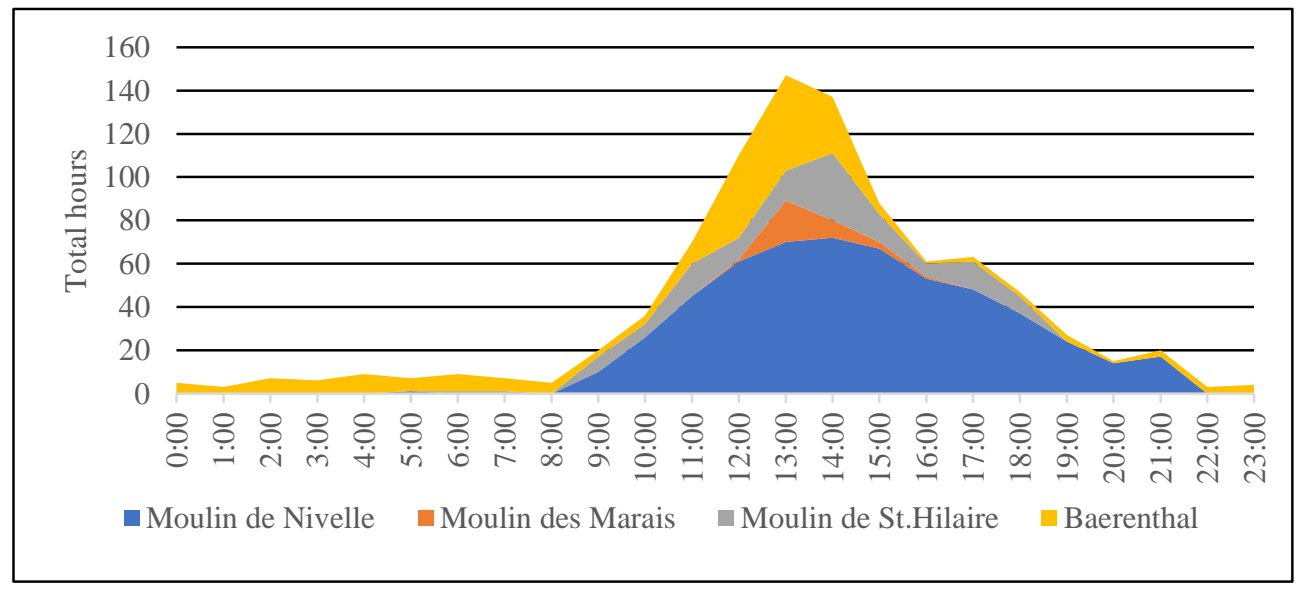

Fig. 3. The moments of the days during which the heterothermia of the water column was present. 
With an even finer temporal analysis it is possible to understand how temperatures evolve at different depths within a day. As an example, see above the evolution of temperatures at Nivelle mill at the surface and at depth during one of the days of maximum thermal heterogeneity of the water column. In the morning, the surface waters are warmer than the deep waters, warming is greatest between the end of the morning and the beginning of the afternoon. The warming of the surface waters stopped during the afternoon and it is the deep waters which warm up most of the time. In the evening the deep waters stop warming up, while the surface gets colder; during the night it is the whole column of water that cools down. Such an evolution has been observed in all the fields of study.

Table 1.

The evolution of temperature at the top ant at the bottom of water column at Neville water mill, the 29/07.

\begin{tabular}{|c|c|c|c|c|c|c|}
\hline $\mathrm{m}$ & $8: 00-10: 00$ & $10: 00-13: 00$ & $13: 00-18: 00$ & $18: 00-22: 00$ & $22: 00-00: 00$ & $00: 00-05: 00$ \\
\hline$-0,1$ & $+0,7^{\circ} \mathrm{C}$ & $+1,8^{\circ} \mathrm{C}$ & $0{ }^{\circ} \mathrm{C}$ & $-0,5^{\circ} \mathrm{C}$ & $-0,3^{\circ} \mathrm{C}$ & $-0,7^{\circ} \mathrm{C}$ \\
\hline$-0,5$ & $+0,3^{\circ} \mathrm{C}$ & $+0,2^{\circ} \mathrm{C}$ & $+1,2^{\circ} \mathrm{C}$ & $0{ }^{\circ} \mathrm{C}$ & $-0,2^{\circ} \mathrm{C}$ & $-0,7^{\circ} \mathrm{C}$ \\
\hline
\end{tabular}

In order to understand if the upstream of weirs retains its lotic features or if the presence of this structure has induced the formation of lentic characteristics, it is necessary to consider the temporality of thermal stratification episodes, rather than their intensity. In fact, in streams too it is possible to observe thermal stratifications (Torgersen et al., 2001, Handcock et al., 2012, Wawrzyniak, 2012), but the difference with those of the water bodies is principally temporal and concerned its duration, frequency and stability (Touchart, 2007, op.cit.). The graphs in Fig. 3 show the evolution of the thermal delta in the different study areas during longer periods of heterogeneity. In Marais and St. Hilaire water mills and in the reach of Baerenthal, micro-stratification episodes occur mainly in the early afternoon and last for an average of one to two hours. Their duration during the summer is so low that we cannot speak of lotic behaviours, but it is more appropriate to speak of an exception to the normal physicochemical homogeneity that characterises the watercourse. Different is the case of Nivelle water mill. Here, the periods of thermal heterogeneity of the water column are not only more intense, but they exceed the first hours of the afternoon and in some cases, they last for a large part of the day. Although their total duration during the hot season is still much lower compared to the moments of homogeneity, during certain periods of the Summer it is possible to speak of an obvious lentic behaviour. For example, between the beginning of July and the end of August the thermal stratification moments amount to $31 \%$ of the total time. During this period the thermal evolution of the water column is clearly polymictic continuous, with thermal stratifications lasting only some hours in the day (Anctil, 2017). This type of evolution is the same that characterises some water bodies, such as the pellicular ponds of some decimetre depth of the Center-West of France (Touchart, 2007 b) or marshes (Oertli \& Frossard, 2013).

How to explain these differences from one study areas to another? The thermal stratification and its degree of intensity are controlled by the work of a stratifying thermal energy and a destructive energy, which in a watercourse are respectively solar energy and the water flow on the bed surface or the wind blowing (Bormans et al., 1997, op.cit.). If in correspondence of the reaches there is a factor that disturbs or accentuates the action of its elements, the thermal evolution of the water column could change much. One of these factors is the vegetation that grows around the channel of the river. Indeed, a number of 
studies has shown that the riparian forest has a great influence on the temperature of rivers, favouring or preventing sunshine (Webb et al., 2008). As we said, throughout the Nivelle water mill reach a fairly dense riparian forest grows, except for clearings that are formed in some places; in this site the thermometers are in correspondence of one of these sectors where the riparian forest is less dense and where the river is exposed to a more intense sunshine. The reach of the Marais water mill too is also sunny throughout its course, as the vegetation is present only on the right bank. Upstream of the St. Hilaire water mill, the river is in a similar situation to that found upstream of the Nivelle water mill, with stream areas that are sunnier than others, but here the sensors were placed in a shady place. These details could explain the low values of delta $\Delta$ in this last field of study and the more marked values observed in the reach of Nivelle water mill, but why was the same thermal operation not observed in the Marais water mill reach that is also exposed to the sun?

Mitrovic et al. (2005) state that a velocity greater than or equal to $0.05 \mathrm{~m} / \mathrm{s}$ is enough to prevent the formation of thermal stratifications. The speed measurements collected throughout the study period in the different study areas show that only at the Nivelle water mill the flow repeatedly had a speed below this threshold. Therefore, upstream of the Nivelle mill all the favourable conditions for the development of a thermal stratification would be brought together.

\section{CONCLUSIONS}

For the first time for French rivers, the collected data provide an insight into the internal thermal operation of water upstream of the river weirs, which makes it possible to distinguish the type of operation that characterises them. Results shows that the presence of a weir is not synonymous of substitution of the lotic characteristics of a watercourse. Indeed, only in one of the study areas among the four studied, that of the Nivelle water mill, a thermal operation similar to that of certain bodies of water was observe, and even then exclusively during the central months of the Summer. During the warmer part of the year, in the other study areas also the physical homogeneity of the water column was "disturbed", but the episodic nature of these moments of heterogeneity consents to classify them as normal thermal stratification observable in watercourses. The appearance of lentic features does not seem to depend on climatic factors, but rather on local factors. Indeed, they have only been observed when certain environmental conditions have been met in the reach, including good exposure to sunshine and a particularly slow flow.

\section{R E F E R E N C E S}

Ausilio, É. (1984). Étude générale de la qualité des Mauves à Meung sur Loire. Assocition des Riverains et des amis des Mauves - Ministère de l'Agriculture - Service d'Aménagement des Eaux de la Region Centre.

Bormans, M., Maier, H., Burch, M., \& Baker, P. (1997, Volume 48). Temperature stratification in the lower River murray, Australia: implication for cyanobacterial bloom development. Marine and Freshwater Research (CSIRO publishing), pp. 647-654.

Choffel, Q., Touchart, L., Bartout, P., \& Al Domany, M. (2017). Temporal and spatial variations in heat content of french pond . Geographia Technica, pp. 9-22.

Csiki, S., \& Rhoads, B. L. (2010). Hydraulic and geomorphological effects of run-of-river dams. Progress in Physical Geography, pp. 755-780.

Escourrou, G. (1982). Le climat de la France. Paris: Presses Universitaires de France. 
Handcock, R. N., Torgersen, C. E., Cherkauer, K. A., Gillespie, A. R., Tockner, K., Faux, N. R., \& Tan, J. (2012). Thermal Infrared Remote Sensing of Water Temperature in Riverine Landscapes. Dans P. E. Carbonneau, \& H. Piégay, Management, Fluvial Remote Sensing for Science and. Chichester: Wiley-Blackwell.

Le Coz, J., Camenen, B., Dramais , G., Ribot-Bruno, J., Ferry, M., \& Rosique, J.-L. (2011). Contrôle des débits réglementaires. Application de l'article L.214-18 du Code de I'environnement. ONEMA.

Lemmin, U. (1995). Limnologie physique. Dans R. Pourriot, \& M. Meybeck, Limnologie générale (pp. 61-106). Paris: Masson.

Malavoi, J.-R., \& Salgues, D. (2011, Février). Arasement et dérasement de seuils. Aide à la définition de Cahier des Charges pour les études de faisabilité Compartiments hydromorphologie et hydroécologie. ONEMA - CEMAGREF.

Mitrovic, M. S., Oliver, R. L., Rees, C., Bowling, L. C., \& Buckney, R. T. (2003). Critical flow velocities for growth and dominance aof Anabaena circinalis in some turbid freshwater rivers. Freshwater Biology, pp. 164-174.

Oertli, B., \& Frossard, P.-a. (2013). Mares et étangs. Écologie, gestion, amenagement et valorisation. Lausanne: Presses polytechniques et universitaires romandes.

Roche, P.-A., Billen, G., Bravard , J.-P., Décamps, H., Pennequin, D., Vindimian, E., \& Wasson, J.-G. (2005, 02). Les enjeux de recherche liés à la directive-cadre européenne sur l'eau. Comptes Rendus Geosciences, pp. 1-25.

Souchon, Y., \& Nicolas, V. (2011, Novembre). Barrages et seuils : principaux impacts environnementaux. ONEMA, CEMAGREF.

Torgersen, C. E., Faux, N. R., McIntosh, B. A., Poage, J. N., \& Norton, J. D. (2001). Airborne thermal remote sensing for water temperature assessment in rivers and streams. Remote Sensing Of Envionnement, pp. 386-398.

Touchart, L. (2001). De la température de l'eau à la géographie des lacs. Université de Limoges, Thèse d'HDR en géographie, $480 \mathrm{p}$.

Touchart, L. (2002). Limnologie physique et dynamique. Paris: L'Harmattan.

Touchart, L. (2007 a). La définition de l'étang en géographie limnologique. Dans A. Angéliaume-Descamps, F. Ardillier-Carras, D. Banas, P. Bartout, C. Bernard, C. G.Genest, ... L. Touchart, Géographie de l'étang. Des theories globales aux pratiques locales. (pp. 14-53). Paris: L'Harmattan.

Touchart, L. $(2007$ b). L'étang et la temperature de l'eau : un ensemble d'impacts géographiques. Dans A. Angéliaume-Descamps, F. Ardillier-Carras, D. Banas, P. Bartout, C. Bernard, C. G.Genest, . . . L. Touchart, Géographie de l'étang. Des theories globales aux pratiques locales. (pp. 119-156). Paris: L'harmattan.

Tricart, J., \& Bravard , J.-P. (1991). L'aménagement des trois plus grands fleuves européens : Rhin, Rhône et Danube. Problèmes et méfaits. Annales de Géographie, pp. 668-713.

Wawrzyniak, V. (2012, 12 12). Etude multi-échelle de la température de surface des cours d'eau par imagerie infrarouge thermique : exemples dans le bassin du Rhône. Thèse de doctorat en Géographie et d'Aménagement soutenue à l'Université Jean Moulin Lyon 3.

Webb, B. W., Hannah, M. D., Moore, D. R., Brown, L. E., \& Nobilis, F. (2008, 02 26). Recent advances in stream and river temperature research. Hydrological Processes, pp. 902-918.

Webster, I. T., Jones, G. J., Oliver, R. L., Bormans, M., \& Sherman, B. S. (1997). Control strategies for cyanobacterial blooms in weir pools. Murray Darling Basin Commission: National Resource Management Strategy.

Wilhem, F. (1960). Die Seen als geographisches Forschungsobjekt. Berichte zur deutschen Landeskunde, pp. 305-321. 